\title{
Stan i doskonalenie kryteriów bezpieczeństwa przed wykolejeniem pojazdów szynowych (1)
}

\begin{abstract}
$W$ artykule przedstawiono aktualny stan wiedzy dotyczqcy bezpieczeństwa przed wykolejeniem jako jednego z podstawowych czynników decydujacym o zastosowaniu, funkcjonalności oraz specyfice pojazdów szynowych. Wraz z ciagłym rozwojem pojazdów szynowych zwiększat się również zakres wiadomości zdobytych na drodze analiz teoretycznych oraz przeprowadzonych badań. Zmieniały się również i kryteria, które stużyty do oceny bezpieczeństwa jazdy pojazdów szynowych.
\end{abstract}

\section{Wprowadzenie}

Przy projektowaniu, badaniach, eksploatacji oraz naprawach pojazdu szynowego problem bezpieczeństwa przed wykolejeniem jest zasadniczym kryterium, przy kwalifikacji pojazdu do ruchu. Jeśli kryterium „bezpiecznej jazdy" nie jest spełnione, to nie ma racji bytu przeprowadzanie pozostałych badań np. badania dynamiczne, badania hamulcowe, badania wytrzymałości poszczególnych elementów tworzących strukturę pojazdu szynowego itd. Nadrzędność tego kryterium dla oceny pojazdu szynowego nie jest kryterium dostatecznym. O spełnieniu kryterium bezpieczeństwa jazdy przed wykolejeniem (z j. niemieckiego „Entgleisungsicherheit” lub „Sicherheit gegen Entgleisen”, z j. angielskiego „safety against derailment”) decydują czynniki:

- związane z pojazdem oraz

- związane z torem.

Nie ma więc $\mathrm{w}$ istocie bezpiecznego toru bez poprawnie zaprojektowanego i utrzymanego pojazdu i na odwrót. Taki podział czynników decydujących o bezpieczeństwie przed wykolejeniem pojazdu szynowego wymaga również podziału kompetencji i współodpowiedzialność za bezpieczną jazdę pojazdu szynowego od:

- producentów pojazdów szynowych,

- zakładów dokonujących przeglądów i napraw pojazdów szynowych,

- służb nadzorujących infrastrukturę kolejową. Artykuł stanowi pierwszą część zagadnienia dotyczącego bezpieczeństwa przed wykolejeniem.

\section{Kryteria bezpieczeństwa przed wykolejeniem}

\subsection{Kryterium wynikające $z$ sil działających $w$ punkcie} styku kolo-szyna w warunkach quasistatycznych

Kryterium bezpieczeństwa przed wykolejeniem zostało wprowadzone w 1908 roku przez Nadala i jako „kryterium Nadala” służy do dnia dzisiejszego do oceny bezpieczeństwa pojazdów szynowych [13]. Ocena bezpieczeństwa przed wykolejeniem sprowadza się do wyznaczenia maksymalnego ilorazu siły prowadzącej $\mathbf{Y}$ oraz siły pionowej $\mathbf{Q}$ ( rys.1). $Z$ tej zwięzłej definicji wynika, że parametr ten wynika $\mathrm{Z}$ warunku równowagi sił na powierzchni styku koła $\mathrm{i}$ szyny. W punkcie styku na obrzeżu koła, koło wywiera nacisk na główkę szyny za pośrednictwem dwóch sił tzn. siły pionowej $\mathbf{Q}$ oraz siły poprzecznej $\mathbf{Y}$ ,natomiast szyna oddziaływuje na koło siłą normalną $\mathbf{N}$ oraz siłą tarcia $\boldsymbol{\mu} \mathbf{N}$.

Wychodząc z zasady równowagi sił można zapisać:

$$
\begin{aligned}
& \begin{array}{l}
\Sigma \mathrm{Fy}=0 \text { czyli } \\
\text { oraz }
\end{array} \\
& \Sigma \mathrm{Fz}=0 \text { czyli } \quad Q=N \cdot \sin \gamma-\mu \cdot N \cdot \cos \gamma+\mu \cdot N \cdot \sin \gamma
\end{aligned}
$$
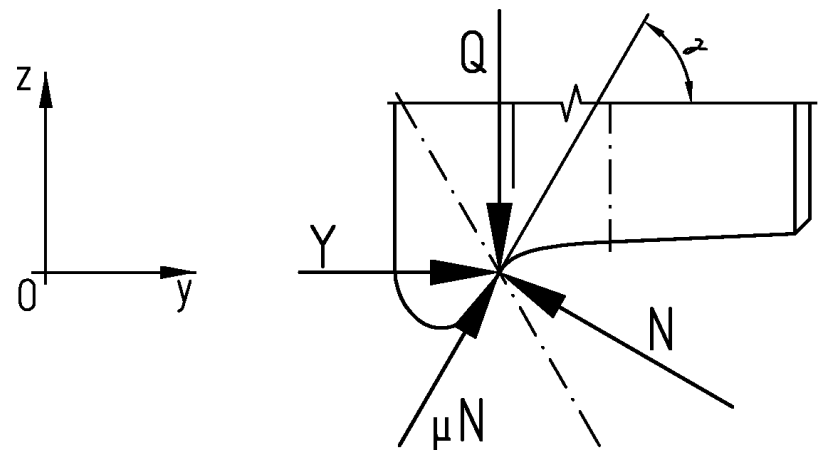

Rys 1. Układ sił działających na koło w punkcie styku kołoszyna

Wynika stąd, że iloraz $Y / Q$, zwany również w literaturze współczynnikiem bezpieczeństwa przeciw wykolejeniu lub w skrócie współczynnikiem wykolejenia [13] (z j. angielskiego „derailment ratio”), wynosi:

gdzie:

$$
\frac{Y}{Q}=\frac{\operatorname{tg} \gamma-\mu}{1+\mu \cdot \operatorname{tg} \gamma}
$$

$\mu$ - współczynnik tarcia pomiędzy kołem i szyna,

$\gamma$ - kąt pochylenia obrzeża.

Tak więc problem sprowadza się do ścisłej zależności współczynnika wykolejenia od współczynnika tarcia oraz kąta pochylenia obrzeża i te dwie wielkości, jako graniczne wielkości umowne, posłużyły do wyznaczenia kryterium „bezpieczeństwa przed wykolejeniem". 
Zależność tego kryterium dla różnych kątów pochylenia obrzeża oraz współczynników tarcia przedstawiono na rys. 2 [13]. W rezultacie długotrwałych i żmudnych poszukiwań skoncentrowanych nad doborem najbardziej przydatnego profilu koła, kąt pochylenia obrzeża dla większości kursujących pojazdów przyjęto jako $\gamma=70^{\circ}$, natomiast współczynnik tarcia jako $\mu=0,36$, co po wstawieniu do (3) daje wartość stosunku $(Y / Q)$ wynoszącą dokładnie 1,2. Stąd kryterium bezpieczeństwa jazdy pojazdu posiadającego koła z kątem pochylenia obrzeża $\gamma=70^{\circ}$ i przy współczynniku tarcia na powierzchni koło/szyna wynoszącym $\mu_{\max }=0,36$ można przedstawić $\mathrm{w}$ sposób następujacy:

$$
\left(\frac{Y}{Q}\right)_{\gamma=70^{\circ}, \mu=0.36} \leq 1,2
$$

Wszelkie inne zapisy w formie skrótowej (bez podania kąta pochylenia obrzeża oraz współczynnika tarcia) prowadzą do uproszczeń w rozumowaniu, mogącym powodować zupełnie błędne decyzje podczas kwalifikacji pojazdu szynowego, zwłaszcza kiedy na drodze badawczej stwierdzono, że pojazd osiaga graniczną wartość ilorazu $(Y / Q)$.

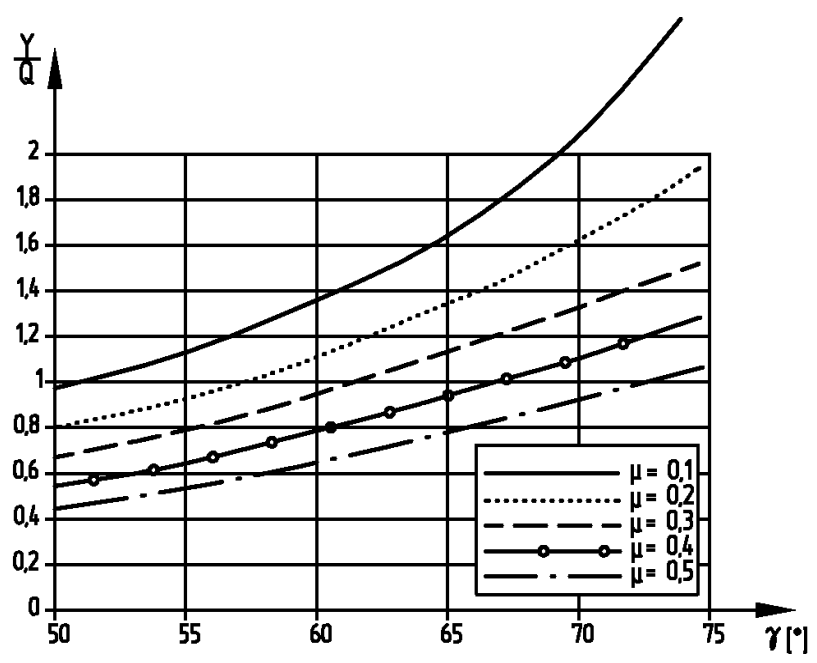

Rys.2. Przebieg funkcji $(Y / Q)$ w zależności od współczynnika tarcia $\mu$ oraz kąta pochylenia $\gamma$ obrzeża profilu koła wg pr EN 14363:2002 [13]

Przyjęcie kryterium 1,2 i jego spelnienie nie gwarantuje w $100 \%$, że pojazd jest bezpieczny. Współczynnik $\mu>0,36$ może przecież wystapić. Potwierdzaja to rozmaite badania zagraniczne przedstawione $\mathrm{w}[2,4,6$ i 7], gdzie okazuje się, że jest możliwe wystąpienie współczynnika $\mu_{\max }=0,6$ !.

Współczynnik ten został również przyjęty jako ekstremalny do analiz statycznych, dynamicznych oraz termicznych obciążeń szyny o profilu UIC 60 wskutek ruchu pojazdów posiadających koło o profilu powierzchni tocznej S1002 (choć przyznano, że najczęściej występującą wartością w eksploatacji kolejowej jest $\mu=0,3)$. Przy współczynniku tarcia $\mu=0,6$ iloraz $Y / Q$ musiałby wynosić 0,81 , aby zagwarantować pełne bezpieczeństwo przed wykolejeniem. W tych warunkach należy wziąc pod uwagę, jakie czynniki wpływają na wzrost współczynnika tarcia. Należą do nich niewątpliwie warunki klimatyczne (bardzo wysokie temperatury, niska wilgotność względna powietrza) i mała prędkość pojazdu (w takim przypadku warunki zbliżają się do qusistatycznych). Ale stąd wynika również drugi wniosek praktyczny dotyczący zmniejszania się współczynnika tarcia, zwłaszcza na torach posiadających łuki o małym promieniu, gdzie występują duże siły prowadzące $\mathrm{z}$ uwagi na duże kąty nabiegania oraz na odcinkach toru o dużej wichrowatości własnej. Układy takie mają częste zastosowania na sieci kolei miejskich ( np. sieci tramwajowej), przyczyniając się jednocześnie do zmniejszenia emisji hałasu oraz zmniejszenia zużycia koło-szyna.

Współczynnik tarcia $\mu$ na normalnej sieci kolejowej można zmniejszyć zgodnie z klasyfikacją przedstawioną $\mathrm{w}$ [7] poprzez:

- działanie urządzeń do smarowania obrzeży zainstalowanych na lokomotywach,

- ewentualne wycieki oleju smarnego z maźnic i układów napędowych,

- systematyczne nanoszenie oleju z urządzeń smarnych przytorowych,

- mgły olejowe pochodzące z przejeżdżających pociagów.

Brak technicznych możliwości określania i pomiarów współczynnika tarcia podczas jazdy pojazdów szynowych był przez długi czas odczuwany przez konstruktorów i badaczy jako bardzo istotny „minus” w metodykach badawczych. Pierwszy przyrząd pomiarowy zwany „trybometrem” został skonstruowany w wyniku współpracy pomiędzy dwoma ośrodkami badawczymi tzn. Derby Research w Anglii i Transport Test Center of Association of American Railroads ( TTC of AAR) w Pueblo i oddany ostatecznie do eksploatacji w sierpniu 1993 roku [7]. Przyrząd ten umożliwia nie tylko rejestrację współczynników tarcia (przyczepności) podczas prób biegowych, ale może być również zastosowany do oceny przyczepności oraz stanu nasmarowania szyn na sieci kolejowej. Pierwsze pomiary za pomoca tego przyrządu zostały wykonane na sieci kolejowej SBB ( Szwajcaria) oraz na ÖBB (Austria) we wrześniu 1993 roku. Z uwagi na konstrukcję przyrządu oraz szczególną czułość techniki pomiarowej nie można było jedynie wykonać pomiarów omawianych współczynników na stykach szyn oraz na zwrotnicach i rozjazdach. Wyniki pomiarów, a zwłaszcza ich rozrzut, były zaskakujące (tym bardziej, że przy ocenie okiem nieuzbrojonym stan szyn oraz stan ich nasmarowania wydawał się być 
równomierny) a mianowicie:

- na powierzchni jezdnej szyny $\mu=0,3$ do $0,65(0,8)$,

- na powierzchni bocznej główki szyny $\mu=0,15$ do 0,4 .

Drugim parametrem, który zmienia się podczas eksploatacji, jest kąt pochylenia obrzeża z racji jego nierównomiernego zużycia. Kąt pochylenia obrzeża $\gamma=70^{\circ}$ ustalono w wyniku żmudnych poszukiwań na drodze doświadczalno-analitycznej. Kąt ten w latach dwudziestych ubiegłego wieku przyjmowano $\gamma=60^{\circ}$ i został zmieniony na wartość $\gamma=70^{\circ}$ dopiero $\mathrm{w}$ latach piećcdziesiątych ubiegłego wieku przy okazji wprowadzenia nowego profilu obrzeża S1002, znanego w literaturze jako tzw. ,profil zużyty”. Po raz pierwszy wprowadzono ten profil do pojazdów trakcyjnych. Oprócz niewątpliwych korzyści związanych ze zużyciem otrzymano również zwiększenie bezpieczeństwa przed wykolejeniem w eksploatacji. Korzystając ze wzoru (3) i podstawiając $\operatorname{tg} 60^{\circ}=1,73$ otrzymuje się wartość współczynnika $(Y / Q)$ wynoszącą tylko 0,84 .

Badania nad optymalizacja profilu koła $\mathrm{z}$ uwagi na bezpieczeństwo przed wykolejeniem trwają nadal. Jednym z przykładów są rezultaty badań doświadczalnych bezpieczeństwa przed wykolejeniem wagonu niskopodłogowego typu Saadkms 4983 („Rollende Landstrasse"), jakie przeprowadzono na liniach zarządów kolejowych SBB (Szwajcaria) oraz ÖBB (Austria). Wagon ten posiadał koła o średnicy $360 \mathrm{~mm}$. Zwiększenie kąta pochylenia obrzeża do $\gamma=75^{\circ}$ (tg $75^{\circ}=3,732$ ) we wprowadzonym profilu SBB 32-3 bez wątpliwości zwiększyło bezpieczeństwo przed wykolejeniem (tabela 1). Siły pionowe Q oraz siły poprzeczne $\mathrm{Y}$ były mierzone według metodyki pomiarowej opracowanej przez ośrodek badawczy w Minden za pomoca specjalnie zbudowanych pomiarowych zestawów kołowych.

Zestawienie wyników badań bezpieczeństwa przed wykolejeniem wagonu Saadkms 4983 na liniach kolejowych SBB ( Szwajcaria) oraz ÖBB ( Austria) wg [7] .

Tabela 1

\begin{tabular}{|c|c|c|}
\hline $\begin{array}{c}\text { Zarząd } \\
\text { kolejowy }\end{array}$ & $\begin{array}{c}\text { Współczynniki } \\
\text { tarcia } \mu\end{array}$ & $\begin{array}{c}\text { Współczynnik } \\
(Y / Q)^{*}\end{array}$ \\
\hline SBB & $0,15 \div 0,20$ & $>3.0$ \\
\hline ÖBB & $0,24 \div 0,35$ & $>2.8$ \\
\hline
\end{tabular}

* współczynnik wykolejenia wynikajacy z bezpośrednich pomiarów sił $Y$ oraz $Q$

Badania z profilem koła o kącie pochylenia $\gamma=75^{\circ}$ wykazały znaczne zwiększenie współczynnika
$(Y / Q)_{\lim }$ na torach o bardzo dobrym stanie utrzymania ( nawet powyżej 3) i niskim stanem zużycia szyn. W przypadku torów o złym stanie utrzymania oraz przy bardzo suchych szynach o wysokiej chropowatości współczynnik ten spadł do wartości 1,3. Negatywnym wynikiem wprowadzenia nowego profilu jest brak zjawiska stopniowego „wykolejenia” przez wspinanie się powierzchni tocznej koła ponad główkę szyny, zamiast którego występuje w tym przypadku zjawisko gwałtownego wykolejenia.

Analizując dalej zależność (Y/Q) jako funkcję $\mathrm{f}(\gamma, \mu)$ można zauważyć, że:

$$
\left(\frac{Y}{Q}\right)=\operatorname{tg}(\gamma-\rho)
$$

gdzie:

$$
\rho=\operatorname{arctg} \mu
$$

$\rho$ - kąt tarcia zgodnie z [6].

Równanie (6) znane jest w literaturze jako kryterium Boedeckera i zostało opublikowane po raz pierwszy w 1886 roku.

Wielkość $\rho$ dla $\mu=0,36$ wg równania (6) wynosi $19,798^{\circ}$, co po podstawieniu do zależności (5) daje tożsamy wynik (4):

$\left(\frac{Y}{Q}\right)=\operatorname{tg}\left(70^{\circ}-19,798^{\circ}\right)=\operatorname{tg} 50,201^{\circ}=1.200$

Wzór (5) w sposób bardzo czytelny wykazuje zależność parametru $(Y / Q)$ od kąta pochylenia obrzeża oraz od współczynnika tarcia. Biorąc pod uwage przebieg funkcji trygonometrycznej $\operatorname{tg}(\gamma-\rho)$ można zauważyć, że im większy kąt $(\gamma-\rho)$, tym kryterium przyjmuje większe wartości i na odwrót. Zależności (3) i (5) obowiązują dla nabiegającego koła zestawu kołowego pojazdu na szynę (prawe koło przedstawione na rys.3). W przepisach oraz w literaturze można spotkać wartość współczynnika tarcia $\mu=0,35$, przy której kryterium bezpieczeństwa przed wykolejeniem jest spełnione. Należy to jednak traktować jako wartość zaokragloną, gdyż dla $\mu=0,35$ współczynnik wykolejenia $(Y / Q)$ wynosi 1,22 .

$Z$ rys. 3 wynika, że układ sił na kole nienabiegającym (koło po lewej stronie) wygląda inaczej niż na kole nabiegającym. Różnica ta wynika $z$ innego położenia punktu styku koła z szyną. Punkt ten znajduje się na powierzchni tocznej koła, gdzie jego profil posiada bardzo małe pochylenie w stosunku do osi wzdłużnej $\mathrm{x}$ i tym należy thumaczyć małe pochylenie siły tarcia $\mu_{y} \cdot N_{2}$. 

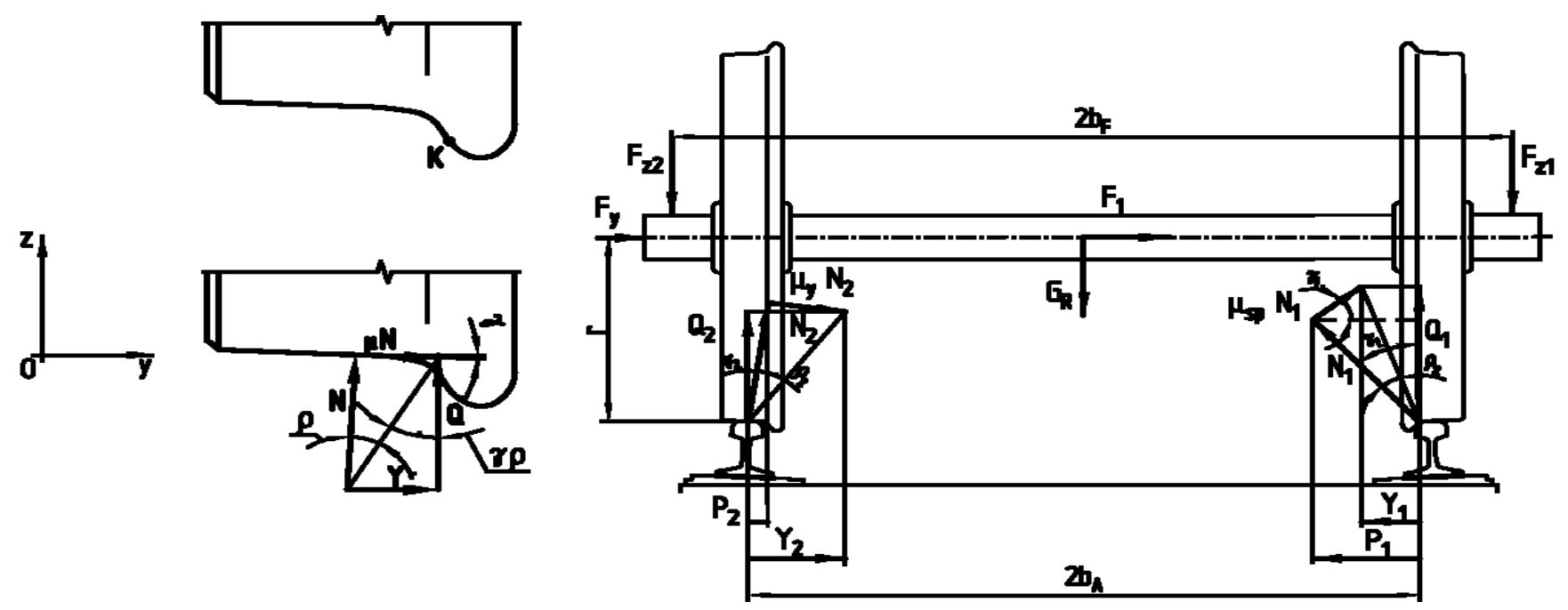

$\mu_{s p}$ - współczynnik tarcia obrzeże-główka szyny

$\mu_{y}$ - współczynnik tarcia na powierzchni tocznej koła podczas ruchu poślizgowego w kierunku poprzecznym

K - punkt skrajny na prostym odcinku boku obrzeża

Rys 3. Układ sił działających na zestaw kołowy pojazdu

W przypadku koła lewego nienabiegającego (rys.3) zależności (1) i (2) przyjmują następującą postać:

$$
\begin{aligned}
& \Sigma \mathrm{Fy}=0 \text { czyli } Y=N \cdot \sin \gamma+\mu N \cos \gamma \\
& \text { oraz } \\
& \Sigma \mathrm{Fz}=0 \text { czyli } Q=N \cdot \cos \gamma-\mu \cdot N \cdot \sin \gamma
\end{aligned}
$$

Wówczas związek (3) przyjmuje następującą postać:

$$
\left(\frac{Y}{Q}\right)=\frac{\operatorname{tg} \gamma+\mu}{1-\mu \operatorname{tg} \gamma}
$$

Wykorzystując „kąt tarcia” $\rho$ zależność (10) można sprowadzić do postaci:

$$
\left(\frac{Y}{Q}\right)=\frac{\operatorname{tg} \gamma+\operatorname{tg} \rho}{1-\operatorname{tg} \rho \cdot \operatorname{tg} \gamma}
$$

Jeśli założyć, na podstawie rys.3 oraz pr EN 14363:2002 [13], że kąt $\gamma$ jest mały w stosunku do „kąta tarcia” $\rho$, to wówczas zależność (11) można sprowadzić do postaci:

$$
\left(\frac{Y}{Q}\right)=\operatorname{tg} \gamma+\operatorname{tg} \rho
$$

Zgodnie z kartą UIC 510-2 [10] wartość $\operatorname{tg} \gamma=0,025$ w związku z czym można wnioskować, że kąt $\gamma=\operatorname{arctg} 0,025=1,43^{\circ}$. Po uwzględnieniu tego założenia oraz używając oznaczenia $\tau=\operatorname{tg} \rho$ jako współczynnika zależnego od kąta nabiegania koła na szynę (poślizg poprzeczny) i od nacisku pionowego koła można zapisać:

$$
\left(\frac{Y}{Q}\right)=\operatorname{tg} \rho+0,025
$$

Współczynnik $\tau$ można określić $\mathrm{z}$ następujących zależności przedstawionych w karcie UIC 510-2 [10] i pr EN 14363: 2002 [13]:

$$
\left(\frac{1}{\tau}\right)^{n}=\left(\frac{1}{a}\right)^{n}+\left(\frac{1}{b \cdot \alpha}\right)^{n}
$$

gdzie:

$$
\begin{aligned}
a & =\frac{Q_{0}^{2}-242,5 \cdot Q_{0}+57150}{100000} \\
b & =\frac{Q_{0}^{2}-242,5 \cdot Q_{0}+219500}{100} \\
n & =0,005 \cdot Q_{0}+2,2
\end{aligned}
$$

natomiast:

$Q_{0}$-jest nominalnym statycznym naciskiem koła na szynę w kN,

$\alpha$ - kąt nabiegania koła na szynę w radianach.

Współczynnika $\tau=\operatorname{tg} \rho$ nie można utożsamiać lub zamieniać na wartość współczynnika tarcia wynikającego z prawa Coulomba $\mu$.

Po przekształceniu wzoru (14) otrzymuje się uproszczoną zależność na obliczenie współczynnika $\tau$ :

$$
\tau=\frac{1}{\sqrt[n]{\left(\frac{1}{a}\right)^{n}+\left(\frac{1}{b \cdot \alpha}\right)^{n}}}
$$

W tabeli 2 przedstawiono wyniki obliczeń (Y/Q) dla nacisków zestawów kołowych na szyny wynoszących $200 \mathrm{kN}$ oraz $225 \mathrm{kN}$, co odpowiada odpowiednio:

$\mathrm{Q}_{0}=100 \mathrm{kN}$ oraz

$\mathrm{Q}_{0}=112,5 \mathrm{kN}$. 


\begin{tabular}{|c|c|c|c|c|c|c|c|}
\hline $\begin{array}{c}\text { Nacisk } \\
\text { zestawu } \\
\text { kołowego } \\
\text { w }[\mathrm{t}]\end{array}$ & $\begin{array}{c}\text { Nacisk } \\
\text { pionowy } \\
\text { koła } \\
\mathrm{w}[\mathrm{kN}]\end{array}$ & $\begin{array}{c}\text { Kąt } \\
\text { nabiegania } \\
\alpha^{o} / \mathrm{rad}\end{array}$ & $\begin{array}{l}\text { Współ- } \\
\text { czynnik } \\
\text { a }\end{array}$ & $\begin{array}{l}\text { Współ- } \\
\text { czynnik } \\
\text { b }\end{array}$ & $\begin{array}{c}\text { Współ- } \\
\text { czynnik } \\
\text { n }\end{array}$ & $\begin{array}{c}\text { Współ- } \\
\text { czynnik } \\
\tau\end{array}$ & $(\mathrm{Y} / \mathrm{Q})$ \\
\hline \multirow{2}{*}{20} & \multirow{2}{*}{100} & 1 & \multirow{2}{*}{0,429} & \multirow{2}{*}{2052,5} & \multirow{2}{*}{2,7} & \multirow{2}{*}{0,4289} & \multirow{2}{*}{0,453} \\
\hline & & 0,01745 & & & & & \\
\hline \multirow{2}{*}{20} & \multirow{2}{*}{100} & $1,5^{\circ}$ & \multirow{2}{*}{0,429} & \multirow{2}{*}{2052,5} & \multirow{2}{*}{2,7} & \multirow{2}{*}{0,4289} & \multirow{2}{*}{0,453} \\
\hline & & 0,02617 & & & & & \\
\hline \multirow{2}{*}{20} & \multirow{2}{*}{100} & 2 & \multirow{2}{*}{0,429} & \multirow{2}{*}{2052,5} & \multirow{2}{*}{2,7} & \multirow{2}{*}{0,4289} & \multirow{2}{*}{0,453} \\
\hline & & 0,03490 & & & & & \\
\hline \multirow{2}{*}{20} & \multirow{2}{*}{100} & 3,211 & \multirow{2}{*}{0,429} & \multirow{2}{*}{2052,5} & \multirow{2}{*}{2,7} & \multirow{2}{*}{0,4289} & \multirow{2}{*}{0,453} \\
\hline & & 0,05604 & & & & & \\
\hline \multirow{2}{*}{22,5} & \multirow{2}{*}{112,5} & 1 & \multirow{2}{*}{0,42525} & \multirow{2}{*}{2048,75} & \multirow{2}{*}{2,7625} & \multirow{2}{*}{0,4252} & \multirow{2}{*}{0,45} \\
\hline & & 0,01745 & & & & & \\
\hline \multirow{2}{*}{22,5} & \multirow{2}{*}{112,5} & 1,5 & 0.42525 & 204875 & 27625 & 04252 & 0.45 \\
\hline & & 0,02617 & $0,4 \angle J \angle J$ & & & & 0,45 \\
\hline 22.5 & 112.5 & 2 & 0.42525 & 2048.75 & 2.7625 & 0.4252 & 0.45 \\
\hline & & 0,3490 & & & & & \\
\hline 225 & 1125 & $3,211^{\circ}$ & 0.42525 & 204875 & 27625 & 04252 & 0.45 \\
\hline & & 0,05604 & & & & & \\
\hline
\end{tabular}

Obliczenia wykonano dla szyn suchych zgodnie ze wzorem (18) według karty UIC 510-2 [10] dla pojazdów $\mathrm{z}$ dopuszczalnym naciskiem zestawu kołowego 20 ton oraz 22.5 tony na oś.

\subsection{Kryterium bezpieczeństwa wynikające $\mathrm{z}$ sil} działających $w$ układzie koło-szyna w warunkach dynamicznych

W raporcie ORE C138 [16], w karcie UIC 518 [11] oraz projekcie normy europejskiej pr EN 14 363:2002 [13] dotyczącej dopuszczenia pojazdu z uwagi na jego własności dynamiczne podczas przejazdu przez tuki o promieniu $\mathrm{R} \geq 250 \mathrm{~m}$ są podane następujące kryteria bezpieczeństwa:

- $\quad$ wg ORE C138 [16] i karty UIC 518 [11]:

$$
\left(\frac{Y}{Q}\right)_{\gamma=70^{\circ}} \leq 0,8
$$

- wg projektu normy europejskiej pr EN 14363:2002 [13]:

$$
(Y / Q)_{\max , \lim } \leq 0,8
$$

Zgodnie z dotychczasowymi doświadczeniami współczynnik $(Y / Q)_{\text {lim }}$ został zweryfikowany dla łuków o promieniu $\mathrm{R} \geq 300 \mathrm{~m}$. Obecnie brak jest przekonywujących dowodów dla obligatoryjnego stosowania tego kryterium dla łuków o promieniach zawartych w przedziale $250 \mathrm{~m} \leq \mathrm{R}<300 \mathrm{~m}$ i aż do momentu przedłożenia pewnych i udowodnionych wyników, kryterium to może być traktowane jako zalecenie.
Przyjęcie takiego kryterium jest związane między innymi wyłącznie ze zmniejszaniem się współczynnika tarcia podczas jazdy, zwłaszcza podczas jazdy z dużymi prędkościami. Sprawdzenia tego kryterium w trakcie prób dynamicznych na trasie można dokonać przez ciagłą rejestrację $\mathrm{w}$ funkcji czasu sił prowadzących $\mathrm{Y}$ oraz pionowych nacisków kół $\mathrm{Q}$ za pomocą pomiarowych zestawów kołowych zainstalowanych $\mathrm{w}$ pojeździe.

\subsection{Kryterium bezpieczeństwa wynikające $\mathrm{z}$ uniesienia koła w stosunku do główki szyny}

Analizując przedstawione zależności oraz rysunki można wyciągnąc wniosek dotyczący definicji wykolejenia w formie klasycznej. Dochodzi do niego wówczas, kiedy koło nabiegające unosi się w stosunku do główki szyny powodując, że punkt styku między kołem i szyną znajdujący się na boku obrzeża koła opuszcza ostatni punkt na prostym odcinku ( punkt K na rys.3) i przechodzi na zaokragloną część obrzeża. W tym momencie należy uznać zjawisko wykolejenia jako dokonane. Ponieważ bok obrzeża ( prosty odcinek obrzeża) dla profilów koła S1002 posiada długość zaledwie paru milimetrów ( dla kół o zakresach średnic $1000 \div 760 \mathrm{~mm}$ wynosi ona $3,91 \mathrm{~mm}$, dla kół o zakresach średnic $760 \div 630 \mathrm{~mm}$ odpowiednio $6,14 \mathrm{~mm}$ oraz dla kół o zakresach średnic $630 \div 330 \mathrm{~mm}-8,97$ $\mathrm{mm})$ to tzw. droga pojazdu, przy której dochodzi do całkowitego uniesienia koła wynosi tylko $0,3 \mathrm{~m}$. Często jednak „droga wykolejenia” jest dłuższa i wynosi parę metrów. W wyniku obserwacji dokonanych podczas badań zjawisk wykolejeń wspomnianego wagonu 
typu Saadkms 4983 okazało się, że pełne wykolejenie występuje przy około $1 / 2$ obrotu koła, co przy uwzględnieniu średnicy tocznej koła wynoszącej 360 mm odpowiadałoby „drodze wykolejenia” wynoszącej około $0,5 \mathrm{~m}$ [7]. Zjawisko wspinania się obrzeża $\mathrm{w}$ stosunku do główki szyny, a tym samym pionowe przesuwanie się punktu styku obrzeża koła $\mathrm{z}$ bokiem główki szyny oraz jego wielkość może być uznane za kryterium wykolejenia i może być sprawdzane na etapie badań. Wielkość uniesienia koła w stosunku do poziomu główki szyny określana jest $\mathrm{w}$ raporcie ORE B55 Rp.8 [15] oraz w pr EN 14363:2002 [13] jako , $d z_{a}$ " . Badania wagonu Saadkms 4983 były przeprowadzone na trasie, natomiast badania wysokości uniesienia koła odbywają się na specjalnym torze badawczym o promieniu $\mathrm{R}=150 \mathrm{~m}$. Wynik badań pojazdu można uznać za pozytywny, jeśli badana wielkość $\mathrm{dz}_{\mathrm{a}} \leq 5 \mathrm{~mm}$.

Badania muszą być przeprowadzane w następujących warunkach:

-szyny toru badawczego muszą być w stanie suchym

(w razie potrzeby muszą być użyte wszystkie dostępne środki, aby zapewnić możliwie wysoki współczynnik tarcia a więc środki czyszczące, odthuszczające oraz piaskowanie szyn),

-tor badawczy musi być wyposażony przynajmniej $\mathrm{w}$ trzy miejsca pomiarowe ( tensometry naklejone na obydwu szynach do pomiarów sił Y oraz Q),

-prześwit toru, profil główki szyny oraz stan utrzymania toru powinien odpowiadać obowiązującym przepisom i normom.

Tor badawczy (rys.4) powinien posiadać łuk o promieniu $\mathrm{R}=150 \mathrm{~m}$, średnią przechyłkę $\bar{u}=0$ oraz stałą wichrowatość wynoszącą $2.5 \% \leq g^{0} \leq 3 \%$.

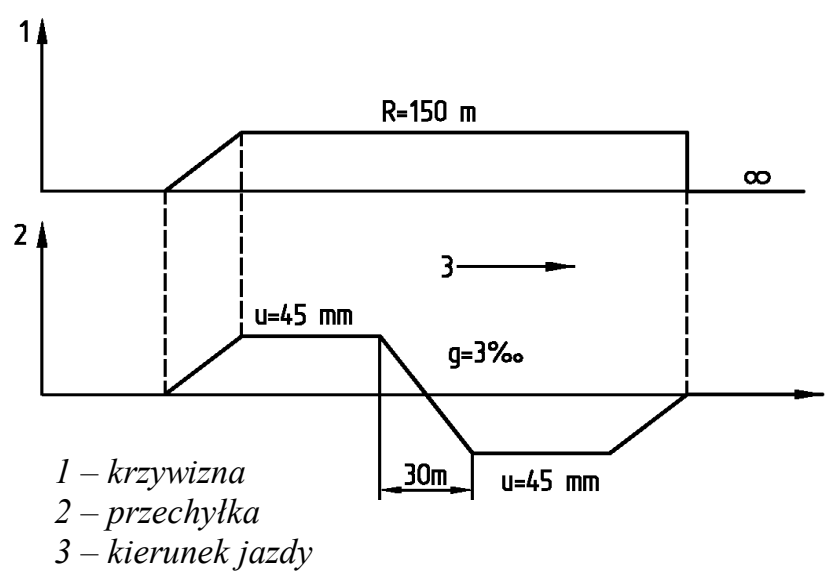

Rys.4. Tor badawczy do przeprowadzania prób bezpieczeństwa przed wykolejeniem

2.4. Kryterium oddziaływania pojazdu na tor $w$ kierunku poprzecznym

2.4.1. Kryterium wymagane przez przepisy europejskie
Jak wynika z rys. 3 podczas jazdy pojazd oddziaływuje na szyny siłami pionowymi oraz poprzecznymi odpowiednio $\mathrm{Q}_{1}$ i $\mathrm{Q}_{2}$ oraz $\mathrm{Y}_{1}$ i $\mathrm{Y}_{2}$. Wielkość tych sił wpływa na wytrzymałość oraz stateczność toru. W przypadku kiedy wielkości te przekraczają wartości dopuszczalne, wówczas tor może ulec przesunięciu wywołanym trwałym odkształceniem toru w planie. Trwałe odkształcenie toru w planie może następować w sposób kumulacyjny na wskutek wielu przejazdów pociagów lub odbyć się w sposób nagły podczas kilku lub jednego przejazdu. Przesunięcie toru może być większe na łukach toru, zwłaszcza wskutek działania sił powodujących wysokie temperatury w szynie. Lokalne przesunięcie toru może być wywołane również przez pojazdy, które przejeżdżają przez tor wykazujący odchyłki geometrii, zwłaszcza w kierunku poprzecznym lub przez silny ruch wężykowania. Należy tutaj jednak uwzględnić, że ważnym parametrem przy dokonywaniu tego rodzaju analiz jest tzw. odkształcenie sprężyste toru, które może znajdować się w przedziale wartości $0,13 \div 0,76 \mathrm{~mm}$ i może mieć wpływ na trwałe odkształcenie toru. $\mathrm{Z}$ tych też względów do analiz bezpieczeństwa przyjmowana jest średnia wartość wynoszącą $0,38 \mathrm{~mm}$. Zbyt duże przesunięcie toru ogranicza bezpieczeństwo jazdy, zmniejsza jej komfort oraz może prowadzić do wykolejenia pojazdu.

W związku z powyższym sformułowano dopuszczalne kryteria oddziaływania pojazdu na tor.

Jako podstawowe kryterium, które jest przedstawione w przepisach międzynarodowych tzn. w karcie UIC 518 [11] i pr EN 14363:2002 [13] stosuje się kryterium Prud'homma, które można przedstawić za pomocą następującej zależności:

gdzie:

$$
\sum Y \leq k_{1} \cdot\left(10+\frac{2}{3} Q_{0}\right)
$$

$\sum Y$ - suma poprzecznych sił prowadzących działających na zestaw kołowy,

$\mathrm{Q}_{0} \quad$ - jak we wzorze (15),

$k_{1}$ - współczynnik zależny od rodzaju pojazdu i przyjmowany jako:

$\mathrm{k}_{1}=0,85$ dla wagonów towarowych oraz

$\mathrm{k}_{1}=1$ dla lokomotyw, zespołów trakcyjnych, wagonów trakcyjnych i wagonów osobowych.

Przyjęcie współczynnika $\mathrm{k}_{1}=0,85$ dla wagonów towarowych i tym samym ograniczenie dopuszczalnej sumy sił prowadzących $\Sigma Y$ jest wynikiem dużego rozrzutu wymiarów geometrycznych oraz gorszego stanu utrzymania toru na trasach kolejowych, gdzie kursuja tego rodzaju pociagi. W uzasadnionych przypadkach przepisy międzynarodowe dopuszczają możliwość zwiększenia tego współczynnika.

Kryterium powyższe wynika $\mathrm{z}$ sumy geometrycznej sił poprzecznych $Y_{1}$ oraz $Y_{2}$ (rys.3), gdzie siła $Y_{1}$ przyjmuje większą wartość, natomiast przyjmując wartość nacisku koła jako $\mathrm{Q}_{0}=0,5 \cdot\left(\mathrm{Q}_{1}+\mathrm{Q}_{2}\right)$ zależność (21) przyjmuje następująca postać: 


$$
\sum Y \leq k_{1} \cdot\left(10+\frac{1}{3}\left(Q_{1}+Q_{2}\right)\right)
$$

gdzie $\mathrm{Q}_{1}$ i $\mathrm{Q}_{2}$ oznaczają siły pionowe przypadające na lewe i prawe koło zestawu kołowego.

Kryterium Prud'homma odnosi się więc do ograniczenia wartości sił poprzecznych wywieranych przez pojazd na szyny tak, aby można było zabezpieczyć tor przed trwałym przesunięciem poprzecznym względem podsypki jako części nawierzchni kolejowej. Kryterium $\mathrm{w}$ takiej postaci dotyczy tylko nawierzchni kolejowej $\mathrm{z}$ thuczniem, podkładami drewnianymi $\mathrm{z}$ ich rozstawem $\leq 0,65 \mathrm{~m}$ oraz szyn o masie jednostkowej wynoszącej $\geq 46 \mathrm{~kg} / \mathrm{m}$. W tym przypadku współczynnik tarcia między podkładami drewnianymi a podsypką thuczniową szacuje się na $\mu=0,45 \div 0,60$. Dla porównania współczynnik tarcia pomiędzy podkładami drewnianymi a podsypką żwirową wynosi $\mu=0,35 \div 0,40$. W przypadku podkładów wykonanych $\mathrm{z}$ betonu zbrojonego oraz podsypki żwirowej współczynnik ten szacuje się na $\mu=0,45$. Dlatego też, podobnie jak w poprzednich przypadkach, podając to kryterium należy mieć na uwadze warunki brzegowe, których ono dotyczy. Ww. warunek ograniczenia masy jednostkowej szyny powoduje, że w przypadku trzech użytkowanych szyn na PKP tzn. $\mathrm{S} 42(42,48 \mathrm{~kg} / \mathrm{m}), \mathrm{S} 49(49,43 \mathrm{~kg} / \mathrm{m})$ oraz S60 $(60,34$ $\mathrm{kg} / \mathrm{m}$ ) kryterium Prud'homma wyrażone zależnościami (21) oraz (22) może dotyczyć jedynie toru z szynami S49 oraz S60 na podkładach drewnianych. W przypadku szyny S42 o mniejszej masie jednostkowej i niższych parametrach wytrzymałościowych należy liczyć się z tym, że kryterium to musi być ostrzejsze, a więc można dopuścić mniejszą wartość sił poprzecznych działających na tor. Przyjęte warunki ograniczające dla stosowania kryterium odpowiadaja tym, które występowały podczas badań dynamicznych przeprowadzonych na SNCF z użyciem specjalnego wagonu trzyosiowego $\mathrm{z}$ przesuwną osią, umożliwiającą realizację siły poprzecznej $\mathrm{Y}$ na powierzchni $\mathrm{z}$ szynami o masie jednostkowej $46 \mathrm{~kg} / \mathrm{m}$ i 1722 podkładami drewnianymi przypadającymi na jeden kilometr toru, co odpowiada odległości pomiędzy podkładami wynoszącymi $0,58 \mathrm{~m}$ [8]. Jednym $\mathrm{z}$ istotnych wniosków jakie wyciagnięto $\mathrm{z}$ tych badań dynamicznych było stwierdzenie, że działanie siły poprzecznej $\Sigma Y$ na granicy określonej wzorem (21) lub (22) występuje tylko wtedy, gdy działanie tej siły odbywa się na długości toru wynoszącej co najmniej $2 \mathrm{~m}$.

$\mathrm{Z}$ punktu widzenia aktualnego stanu wiedzy warunkami ograniczającymi lub warunkami brzegowymi tego kryterium są:

- opór poprzeczny podkładu toru na przemieszczenia (w przypadku podkładów drewnianych wartość ta wynosi $3,40 \div 4,10 \mathrm{kN} / \mathrm{m}$ wg [9], natomiast w przypadku podkładów betonowych $8,9 \div 10,7$ $\mathrm{kN} / \mathrm{m}$ wg [5]),
- współczynnik tarcia w układzie podkłady/ tłuczeń ( jako funkcja obciążenia pionowego oraz ilości przejazdów),

- histereza w układzie podkłady/ thuczeń ( zachowanie się przy dociążeniu i odciążeniu ) przy obciążeniu cyklicznym,

- parametry geometryczne rozpatrywanego odcinka toru,

- odchyłka temperatury szyny od wartości zerowej, która wyraża obciążenie cieplne,

- krzywizna łuku toru,

- występujące odchyłki geometryczne toru,

- pionowy moduł sprężystości ( na podstawie badań amerykańskich oraz europejskich wynosi on 69 $\mathrm{MPa}$ ).

Analizując wzór (21) można wyciągnąć wniosek, że celowym jest budowa tras kolejowych, które realizują oddzielenie ruchu towarowego od pasażerskiego, zwłaszcza dla zespołów trakcyjnych przeznaczonych do transportu osobowego $\mathrm{z}$ wysokimi prędkościami. Kryterium tego nie należy rozpatrywać jako bezpośredniego czy klasycznego związanego z bezpieczeństwem przed wykolejeniem, ale powinno być równolegle rozpatrywane $\mathrm{z}$ kryteriami przedstawionymi $\mathrm{w}$ p.2.1, 2.2 oraz 2.3 .

\subsubsection{Kryterium wymagane przez przepisy ame- rykańskie}

W amerykańskich przepisach kryterium Prud'homma podawane jest w następującej formie:

gdzie:

$$
\frac{L}{V}=\frac{2,25}{V}+0,33
$$

L-obciążenie poprzeczne toru „netto” w kilopondach,

V-statyczny nacisk pionowy zestawu kołowego na

szyny w kilopondach.

Zgodnie z [5] kryterium powyższe obowiązuje dla toru prostego.

Po wstawieniu zależności $1 \mathrm{kp}=4,449 \mathrm{kN}$ ( 1 poundforce $=0,4536 \mathrm{kG})$ i pomnożeniu obydwu stron równania przez $V$ otrzymuje się identyczne równanie jak (21) przy uwzględnieniu, że $\mathrm{k}_{1}=1$ oraz $\mathrm{V}=2 \mathrm{Q}_{0}$. Współczynnik $\mathrm{k}_{1}=0,85$ jest $\mathrm{wg}$ [5] nie tyle związany $\mathrm{z}$ pojazdem ale jest propozycją twórcy kryterium ( Prud'homma), aby dostosować powyższe kryterium do łuków i sił powodujących wywiązywanie się ciepła.

\subsubsection{Kryterium wymagane przez Federal Railro- ad Administration (amerykański Zarząd Fe- deralny Kolei) dla ruchu $z$ wysokimi pręd- kościami}

W związku z rozwojem transportu osobowego z wysokimi prędkościami Federal Railroad Adminstration podległe amerykańskiemu Ministerstwu Transportu ustaliło, że zespoły trakcyjne przystosowane do wysokich prędkości powinny być poddane obligatoryjnym próbom biegowym na trasie, na której będą 
eksploatowane oraz siły koło-szyna będą mierzone co roku przez pojazd referencyjny. Transport $\mathrm{z}$ wysokimi prędkościami definiuje się zgodnie z przepisami ( np. europejskimi pr EN 14363:2002 [13] ), który odbywa się $\mathrm{z}$ prędkościami $\mathrm{v} \geq 250 \mathrm{~km} / \mathrm{h}$. Wymóg bezpieczeństwa $\mathrm{z}$ uwagi na boczne przesunięcie toru sformułowano zgodnie z następującą zależnością:

$$
\frac{L}{V}=0,5
$$

gdzie L i V jak we wzorze (23).

Wymaganie to zostało zaproponowane przez grupe ekspertów technicznych w 1998 roku w ramach rozwoju norm dla transportu osobowego $\mathrm{z}$ wysokimi prędkościami na podstawie ocenianego jako bardzo ostrożne kryterium Prud'homma oraz w oparciu o wyniki badań dynamicznych przeprowadzonych na zespołach trakcyjnych typu X2000 oraz ICE i Amtrak. Zależność (24) można zapisać przyjmując $\mathrm{V}=2 \mathrm{Q}_{0} \quad \mathrm{~W}$ następujący sposób:

$$
L=Q_{0}
$$

Przyjmując maksymalny nacisk pionowy koła na szynę $\mathrm{Q}_{0}=75 \mathrm{kN}$ na przykładzie nowoczesnych układów biegowych TR 400 produkcji Bombardier Transportation przeznaczonych do zespołów trakcyjnych kursujących z maksymalną prędkością $350 \mathrm{~km} / \mathrm{h}$ zgodnie z [3] otrzymuje się dopuszczalną wartość siły poprzecznej $L$ wynoszącą $75 \mathrm{kN}$, natomiast zgodnie $\mathrm{z}$ zależnością (21) przy uwzględnieniu $k_{l}=1$ otrzymuje się wartość $L=60 \mathrm{kN}$. Wynika $\mathrm{z}$ tego, że kryterium Prud'homma uwzględnia $\mathrm{w}$ tym przypadku $25 \%$ zapas bezpieczeństwa.

W wyniku tak sformułowanego kryterium okazało się, że jego spełnienie może powodować zwiększenie nakładów na utrzymanie toru. Pojawiła się w związku z tym konieczność zrewidowania dotychczasowych poglądów na obciążenia boczne toru oraz sformułowanie kryteriów, które zawierałyby mniejszy zapas bezpieczeństwa niż wspomniane kryterium Prud'homma. Główny zarzut jaki jest kierowany do tego kryterium polega na tym, że jest ono sformułowane tylko na podstawie badań na lekkim torze z podkładami drewnianymi i nie pozwala na wyciagnięcie wniosków co do maksymalnych sił poprzecznych dla innych rodzajów toru. Poza tym uwzględnia ono wpływ siły poprzecznej o stałej wartości, podczas gdy z wyników badań dynamicznych można wyciagnąć wniosek, że w rzeczywistej eksploatacji pojawiają się siły z maksymalnymi wartościami występującymi na krótkich odcinkach. Stwierdzenie, że kryterium Prud'homma nie jest kryterium ostatecznym i że będzie podlegało stałemu rozwojowi znajduje się $\mathrm{w}$ [8]. Już z początkiem lat siedemdziesiątych ubiegłego wieku wyrażono pogląd, że jeśli tor jest dobrze ustabilizowany, a tym samym cechuje się dużą odpornością na przesunięcia poprzeczne, to w tym przypadku obowiązuje zależność przedstawiona $\mathrm{w}[8]$ :

$$
\sum Y=0,85 \cdot\left(2,5+0,6 \cdot\left[Q_{1}+Q_{2}\right]\right)
$$

Podstawiając $\mathrm{Q}_{1}=\mathrm{Q}_{2}=2 \mathrm{Q}_{0}$ i podstawiając $\mathrm{Q}_{0}=75 \mathrm{kN}$ otrzymuje się wartość siły Y lub $L=78,625 \mathrm{kN}$.

W przypadku zależności (26) dopuszcza się znacznie większą wartość siły poprzecznej.

Celem dalszych analiz dopuszczalnej siły poprzecznej w USA zbudowano oprogramowanie komputerowe bazujące na modelu matematycznym odkształceń toru TREDA (skrót nazwy Track Residual Deflection Analysis) [5]. W wyniku przeprowadzonych analiz symulacyjnych zaproponowano następujący wzór obowiązujący dla ruchu $\mathrm{z}$ wysokimi prędkościami $\mathrm{w}$ pełnym zakresie prędkości:

$$
\frac{L}{V}=0,28+\frac{4,46}{V}
$$

gdzie $L$ i $V$ jak we wzorze (23).

Wzór (27) po pomnożeniu obydwu stron przez $V$ oraz po wstawieniu $1 \mathrm{kp}=4,449 \mathrm{kN}$ otrzymuje postać:

$$
L=0,28 \cdot V+19,84
$$

Kryterium to wyprowadzono dla ruchu na torze spawanym, bez złączek pomiędzy szynami oraz dla promienia $\mathrm{R} \geq 291 \mathrm{~m}$. Podstawiając $V=2 \mathrm{Q}_{0}=150 \mathrm{kN}$ ( dla zespołów trakcyjnych wyposażonych $\mathrm{w}$ nowoczesny układ trakcyjny TR 400 ) otrzymuje się $L=61,84 \mathrm{kN}$, a więc dopuszcza większą siłę aniżeli przepisy europejskie. Różnica ta będzie zwiększała się wraz ze wzrostem statycznego nacisku bazowego koła $\mathrm{Q}_{0}$. Przyjęty do analiz model TREDA został zweryfikowany z wynikiem pozytywnym poprzez badania stanowiskowe oraz ruchowe, które przeprowadzono w ośrodku badawczym Transportation Technology Center w Pueblo (Colorado). Ostateczne przyjęcie nowych kryteriów jest $\mathrm{w}$ fazie weryfikacji polegającej na analizie badań dynamicznych. Rozwój tego kryterium wyjaśniają analizy wzoru (21) oraz (22) podane w [8 i 9]. Wzory (21) oraz (22) wywodzą się z wyprowadzonej zależności mającej charakter ogólny:

$$
\sum Y=\frac{2 L_{y}}{l} \cdot H_{0}+\frac{2 L_{y}}{L} \cdot f \cdot Q_{0}
$$

przy uwzględnieniu, że:

$$
L_{y}=\sqrt[4]{\frac{4 E \cdot I_{y}}{U_{y}}}
$$

gdzie:

$\mathrm{L}_{\mathrm{y}}$ - współczynnik względnej sztywności toru w płaszczyźnie poziomej,

E - moduł Younga dla stali,

$\mathrm{I}_{\mathrm{y}}$ - moment bezwładności szyny względem osi y prostopadłej do poziomu wyznaczonego przez główki szyny,

$\mathrm{U}_{\mathrm{y}}$ - współczynnik sprężystości podparcia szyny,

1 - rozstaw podkładów, 
$\mathrm{H}_{0}$-opór początkowy w kierunku poprzecznym podkładu kolejowego dla nacisku pionowego koła $\mathrm{Q}_{0}=0$ (rośnie wraz ze wzrostem nacisku pionowego zgodnie z zależnością $\mathrm{H}=\mathrm{H}_{0}+2 \mathrm{fQ}_{0}$ ),

L -współczynnik względnej sztywności szyny i podparcia szyny,

F - współczynnik tarcia podkładu drewnianego po podsypce.

Jeśli uwzględnić $\mathrm{f}=0,5$ oraz $\mathrm{L}=1,5 \mathrm{~L}_{\mathrm{y}}, \mathrm{H}_{0}=250 \div 300$ $\mathrm{kN}$ wówczas dochodzi się do zależności określonej wzorami (21) oraz (22).

\subsection{Kryterium oddziaływania pojazdu na tor $w$ kierunku pionowym}

Kolejnym kryterium wpływającym na bezpieczeństwo jazdy i zabezpieczającym pojazd pośrednio przed wykolejeniem jest kryterium dopuszczalnego nacisku pionowego koła na szynę. To kryterium jest sformułowane w karcie UIC 518 [11] oraz pr EN 14363:2002 [13] i ma następującą postać:

$$
Q_{\text {max }, \lim }=90+Q_{0}
$$

gdzie:

$\mathrm{Q}_{\max , \lim }$ - maksymalny nacisk koła na szynę wyrażony $\mathrm{w} \mathrm{kN}$ podczas jazdy.

Z zależności (31) wynika, że nacisk koła na szynę podczas jazdy składa się z dwóch części: nacisku statycznego $\mathrm{Q}_{0}$ oraz nadwyżki dynamicznej, której udział przyjęto na poziomie $90 \mathrm{kN}$. Zależność (31) obowiązuje $\mathrm{W}$ zakresie do maksymalnej wartości $\mathrm{Q}_{0}=112,5 \mathrm{kN}$, co odpowiada dopuszczalnemu naciskowi na oś wynoszącemu $225 \mathrm{kN}$ ( 22,5 t/oś). Dla takiego przypadku $\mathrm{Q}_{\max , \lim }=202,5 \mathrm{kN}$. Wartość ta podana jest $\mathrm{w}$ ww. przepisach $\mathrm{w}$ zaokragleniu jako 200 kN. Kryterium (31) obowiązuje dla szyn o masie jednostkowej $\geq 46 \mathrm{~kg} / \mathrm{m}$ (szyny typu S49 i S60) oraz o parametrach wytrzymałościowych $R_{m} \geq 700 \mathrm{~N} / \mathrm{mm}^{2}$. W przypadku nowo dopuszczonego ruchu $\mathrm{z}$ naciskiem statycznym $2 \mathrm{Q}_{0}=250 \mathrm{kN}$ na wybranych liniach kolejowych zarządów europejskich UIC obowiązują przepisy nowo wydanej karty UIC 518-2 [12] i $\mathrm{Q}_{\max . \lim }=215 \mathrm{kN}$.

Wartość $\mathrm{Q}_{\text {max,lim }}$ jest również zależna od prędkości jazdy pojazdu, co jest przedstawione w tabeli 3 .

Zależność $\mathbf{Q}_{\text {max,lim }}$ od prędkości pojazdu wg karty UIC 518 [11]

Tabela 3

\begin{tabular}{|r|c|c|c|}
\hline L.p. & Zakres prędkości & Kryterium & $\begin{array}{c}\text { Uwa- } \\
\text { gi }\end{array}$ \\
\hline 1 & $\mathrm{v}_{\max } \leq 160 \mathrm{~km} / \mathrm{h}$ & $\mathrm{Q}_{\max , \lim } \leq 200 \mathrm{kN}$ & \\
\hline 2 & $160<\mathrm{v}_{\max } \leq 200 \mathrm{~km} / \mathrm{h}$ & $\mathrm{Q}_{\max , \lim } \leq 190 \mathrm{kN}$ & \\
\hline 3 & $200<\mathrm{v}_{\max } \leq 250 \mathrm{~km} / \mathrm{h}$ & $\mathrm{Q}_{\max , \lim } \leq 180 \mathrm{kN}$ & \\
\hline 4 & $250<\mathrm{v}_{\max } \leq 300 \mathrm{~km} / \mathrm{h}$ & $\mathrm{Q}_{\max , \lim } \leq 170 \mathrm{kN}$ & \\
\hline 5 & $\mathrm{v}_{\max }>300 \mathrm{~km} / \mathrm{h}$ & $\mathrm{Q}_{\max , \lim } \leq 160 \mathrm{kN}$ & \\
\hline
\end{tabular}

Kolejnym kryterium wymienionym w przepisach międzynarodowych a ograniczającym wartość quasistatycznej siły pionowej oddziaływania koła na szyne na łukach o bardzo małym promieniu ( $250 \leq \mathrm{R}<400$ m) oraz na tukach o małym promieniu ( $400 \leq \mathrm{R}<600 \mathrm{~m})$ jest maksymalna wartość quasistatycznej siły pionowej $\mathrm{Q}_{\text {qstlim }} \leq 145 \mathrm{kN}$.

\section{Bezpieczeństwo przed wykolejeniem jako funkcja cech pojazdu oraz toru}

\subsection{Uwagi ogólne}

Kryterium bezpieczeństwa przed wykolejeniem przedstawione $\mathrm{w}$ p.2.1 przeanalizowano pod kątem oddziaływania w układzie koło-szyna. Skoncentrowano się tutaj przede wszystkim na czynnikach zawartych po prawej stronie równania (3) tj. kącie pochylenia obrzeża koła oraz współczynniku tarcia. Wielu teoretycznych i praktycznych spostrzeżeń może jednak dostarczyć lewa strona równania. Współczynnik wykolejenia jest definiowany tu jako stosunek poprzecznej siły prowadzącej Y do nacisku pionowego koła Q. Siły te w trakcie jazdy i eksploatacji pojazdu przyjmują wartości zmienne. Czynnikami, które moga zwiększyć ten współczynnik ponad dozwoloną wartość 1,2 są nadmierny wzrost siły prowadzącej oraz odciążenie koła zestawu kołowego i zależą one od budowy zarówno samego pojazdu jak również i toru. Czynnikami mającymi wpływ na współczynnik bezpieczeństwa przed wykolejeniem $\mathrm{W}$ wyniku odciążenia koła $\Delta \mathrm{Q}$ są:

- ze strony pojazdu:

- sztywność skrętna pudła pojazdu,

- sztywność skrętna ramy wózka w kombinacji ze sztywnością skrętną usprężynowania pierwszego stopnia,

- mimośrodowość środka masy pojazdu w płaszczyźnie poziomej,

- tarcie wywiązujące się podczas wichrowania.

- ze strony toru:

- wichrowatość na krzywych przejściowych toru,

- dodatkowa wichrowatość spowodowana błędami we wzajemnym położeniu szyn,

- nadmiar lub niedostateczność przechyłki toru.

Czynnikami mającymi wpływ na współczynnik bezpieczeństwa przed wykolejeniem w wyniku zwiększenia siły prowadzącej Y są:

- ze strony pojazdu:

- rozstaw zestawów kołowych wózka ( baza wózka) względnie rozstaw zestawów kołowych wagonów dwuosiowych,

- moment obrotowy wózka ( układu biegowego) względem nadwozia,

- sztywność wzdłużna i poprzeczna prowadzenia zestawu kołowego w usprężynowaniu pierwszego stopnia. 
- $\quad$ ze strony toru:

- promień łuku toru,

- błędy ułożenia toru.

Przy tak sklasyfikowanych czynnikach, w raporcie ORE B55 Rp.8 [15] są przedstawione przypadki, które zwiększają prawdopodobieństwo wykolejenia:

- przejazd pojazdu przez małe łuki toru, kiedy powstają większe siły prowadzące,

- małe naciski kół podczas jazdy pojazdu (cechującym się małą masą własną) w stanie próżnym lub częściowo załadowanym,

- duża sztywność skrętna pojazdu, która sprzyja odciążeniu kół podczas przejazdu przez tor wichrowaty,

- mała prędkość jazdy, podczas której duże siły Q oraz Y powstają w warunkach qusistatycznych,

- przejazd przez odcinki toru z szynami suchymi, dającymi niekorzystne warunki cierne.

3.2. Kryterium bezpieczeństwa przed wykolejeniem wynikające $z$ odciążenia koła $\Delta Q$ oraz działania siły prowadzącej $\mathbf{Y}$

Biorąc pod uwagę, że współczynnik bezpieczeństwa przed wykolejeniem jest funkcją dwóch sił a więc siły prowadzącej $Y_{a}$ oraz rzeczywistego nacisku koła na szynę $Q_{a}$ (indeks ,a” oznacza, że koło znajduje się na zewnętrznej szynie łuku toru) kryterium przedstawione we wzorze (3) można zastapić formułami, które mają już bardziej praktyczny charakter, czyli:

$$
\frac{Y}{Q}_{a}=\frac{Y_{a}\left(R, a_{q}, Q_{o j}\right)}{Q_{a}}
$$

gdzie:

$\mathrm{R}$ - promień łuku toru,

$\mathrm{a}_{\mathrm{q}}$ - przyspieszenie poprzeczne

oraz

$$
Q_{a}=Q_{o j}-\Delta Q_{f z o}-\Delta Q_{t} \pm \Delta Q_{f y}
$$

gdzie:

$\mathrm{Q}_{\mathrm{a}} \quad$ - rzeczywisty nacisk pionowy koła nabiegającego na szynę,

$\mathrm{Q}_{\mathrm{oj}} \quad$ - nominalny (średni) nacisk koła j-tego zestawu kołowego na szynę,

$\Delta \mathrm{Q}_{\text {fzo }}$-odchyłka nacisku koła na szynę wynikająca $\mathrm{z}$ szerokości zmierzonej pętli histerezy $\mathrm{z}$ tarcia $\mathrm{w}$ zawieszeniu oraz $w$ układzie oparcia nadwozia zmierzonej dla każdego pojazdu wg metodyki przedstawionej w pr EN 14 363:2002 [13] oraz raporcie ORE B55 Rp.8 [15],

$\Delta Q_{t}$ - zmiana pionowego nacisku koła na szynę spowodowana wichrowatością toru,

$\Delta \mathrm{Q}_{\mathrm{fy}}$-odchyłka nacisku koła na szynę spowodowana działaniem poprzecznej siły łożyskowej $\quad \mathrm{F}_{\mathrm{y}}$ (rys.3).
Po wstawieniu zależności (33) do ( 32) otrzymuje się:

$$
\frac{Y}{Q_{a}}=\frac{Y_{a}\left(R, a_{q}, Q_{o j}\right)}{Q_{o j} \quad \Delta Q_{f z o} \quad \Delta Q_{t} \pm \Delta Q_{F y}}
$$

Zmianę nacisku koła dla pojazdów wózkowych, wywołanego wichrowatością $\Delta \mathrm{Q}_{\mathrm{t}}$, można wyrazić za pomocą następującego wzoru:

$$
\Delta Q_{t}=c_{t A\left(2 a^{*}\right)} \cdot g^{*}+c_{t A\left(2 a^{+}\right)} \cdot g^{+}
$$

gdzie:

$c_{t A\left(2 a^{*}\right)^{-}}$całkowita sztywność skrętna pojazdów wóz-

kowych przy wichrowatości odniesionej do bazy wózka $2 \mathrm{a}^{*}$ wyrażona $\mathrm{w} \mathrm{kN} / \mathrm{mm}$ lub $\mathrm{w}$ $\mathrm{kN} / \%$,

$\mathrm{g}^{*}$ - wichrowatość pojazdu mierzona na bazie wagonu wyrażona w mm lub w \%o,

$c_{t\left(2 a^{+}\right)^{-}}$całkowita sztywność skrętna pojazdów wóz-

kowych przy wichrowatości odniesionej do bazy wagonu $2 \mathrm{a}^{+}$, wyrażona $\mathrm{w} \mathrm{kN} / \mathrm{mm}$ lub $\mathrm{w}$ $\mathrm{kN} / \%$,

$\mathrm{g}^{+}$- $\quad$ wichrowatość pojazdu mierzona na bazie wózka wyrażona w mm lub w $\%$.

Zgodnie z raportem ORE B55 Rp.8 [15] wichrowatość $\mathrm{g}^{*}$ lub g $^{+}$wyraża się odpowiednio wzorami:

$$
\begin{gathered}
g^{*}=\frac{15}{2 a^{*}}+2 \text { przy zakresie obowiązywa- } \\
\text { nia4,5 } \mathrm{m}<2 \mathrm{a}^{*}<20 \mathrm{~m}
\end{gathered}
$$

oraz

$$
\begin{gathered}
g^{+}=7-\frac{5}{2 a^{+}} \text {przy zakresie obowiązywa- } \\
\text { nia } 1,3 \mathrm{~m}<2 \mathrm{a}^{+}<4,5 \mathrm{~m}
\end{gathered}
$$

Wzory (34) oraz (35) określające wichrowatość toru wynikaja z jego trajektorii (trasowania) oraz stanu utrzymania. Wartość $15 \mathrm{~mm}$ podana w (36) jest graniczną odchyłką wysokościową mierzoną pomiędzy obydwoma tokami szyn. Natomiast wartość 2 oznacza pochylenie rampy przechyłkowej zewnętrznego toku szyn przy kształtowaniu odcinków łączących tor prosty $\mathrm{z}$ łukiem o określonym promieniu oraz przechyłce. Tok wewnętrzny szyn toru jest usytuowany wciąż na tym samym poziomie jak tor prosty, jednak poszerzenia toru na łukach wykonuje się przez odsunięcie szyny toku wewnętrznego szyny od środka łuku toru ( np. za pomoca krzywej przejściowej). Jak wynika z (36) w przypadku dłuższych pojazdów wpływ wichrowatości na odciążenie koła będzie mniejszy, aniżeli w przypadku pojazdów posiadających tzw. krótką bazę. Wielkość pochylenia rampy przechyłkowej była przedmiotem rozlicznych uzgodnień i dyskusji pomiędzy przedstawicielami przemysłu oraz infrastruktury kolejowej. Zależność (36) była przedmiotem 
licznych modyfikacji. Wcześniejsze postacie wzoru miały bardziej rygorystyczny charakter. W literaturze [8] podano, powołując się na badania ORE, wcześniejszą edycję wzoru (36), a mianowicie:

$$
\lim g_{1}^{0}=g^{*}=\frac{20}{2 a^{*}}+3 \leq 7 \%
$$

Z wzoru (38) wynika, że pochylenie rampy przechyłkowej wynosi $3 \%$, natomiast maksymalna wysokość odchyłki wysokościowej wynosi $20 \mathrm{~mm}$. Kryterium to powstało $\mathrm{w}$ wyniku statystycznego opisu parametrów wichrowatości $\mathrm{w}$ danym stanie nawierzchni kolejowej na podstawie szeregu pomiarów przeprowadzonych na sieciach kolejowych DB, NS, ÖBB, PKP i SNCF. Założono, że pomiary przeprowadzone na odcinkach toru o łącznej długości $7000 \mathrm{~km}$ tworzą wystarczającą postawę do ustalenia zależności pomiędzy wichrowatością toru a bazą pojazdu. Kryterium (37) jest łagodniejsze dla pojazdów szynowych i wynika $\mathrm{z}$ założenia, że wykolejenie spowodowane wichrowatością toru jest uwarunkowane niskim prawdopodobieństwem jednoczesnego wystapienia ekstremalnych warunków geometrii toru, czynników związanych z pojazdem oraz warunków eksploatacyjnych. W tej sytuacji należy uznać, że wielkość $2 \%$ oraz $15 \mathrm{~mm}$ są odpowiednio umownymi wartościami pochylenia rampy przechyłowej oraz nierówności toków szyn, których wystąpienie jednoczesne może odbywać się z dużym prawdopodobieństwem. Jak podaje raport ORE B55 Rp.8 [15], to założenie musiało stanowić wyjaśnienie dlaczego odnotowano wcześniej tak małą ilość wykolejeń wagonów towarowych pomimo, że wagony te nie spełniały ustalonej sztywności skrętnej określonej w szóstym wydaniu raportu ORE B55 Rp.6. W związku z tym wichrowatość $\lim g_{1}^{0}$ nie była już przydatna więcej $\mathrm{w}$ ocenie bezpieczeństwa przed wykolejeniem pojazdów szynowych i zastąpiono ją wzorem (36).

Zależność (37) wynika z badań, jakie przeprowadzono badając bezpieczeństwo przed wykolejeniem na torze posiadającym wichrowatość $7 \%$ i odnosi się ona do bazy wynoszącej $5 \mathrm{~m}$ pojazdu badawczego uznanego jako pojazd referencyjny ( najmniejsza baza wagonów towarowych dwuosiowych). Przy uwzględnieniu $2 \mathrm{a}^{+}=5 \mathrm{~m}$ maksymalna wichrowatość $\mathrm{g}^{+}$wynosi $6 \%$.

Wartość ta odpowiada dokładnie tej, którą określono jako maksymalną w przepisach D1 obowiązujących na PKP [14]. Drugim istotnym postanowieniem ww. przepisów jest dopuszczenie ramp przechyłkowych o pochyleniu maksymalnym wynoszącym $i_{\max }=2,5 \%$. Na trasach kolejowych innych zarządów europejskich pochylenie ramp przechyłkowych wynosi podobnie jak w Polsce $i_{\max }=2,5 \%$, natomiast wyjątek stanowi SNCF ( Francja), która stosuje $i_{\max }=1,5 \%$ [1]. Parametr ten jest uwzględniony we wzorze (36) (wartość umowna 2\%).

Projekt normy europejskiej EN 14363:2002 [13] wprowadził kolejne zmiany $\mathrm{w}$ zakresie kryteriów wichrowania pojazdów wózkowych przedstawionych w (36) oraz (37).

Wichrowatość $\mathrm{g}^{*}$ lub $\mathrm{g}^{+}$wyraża się odpowiednio wzorami:

$$
g^{*}=\frac{15}{2 a^{*}}+2 \quad \text { dla } 2 \mathrm{a}^{*} \leq 20 \mathrm{~m}
$$

natomiast dla pojazdów wieloczłonowych posiadających bazę $2 a^{*}>20 \mathrm{~m}$ obowiązuje zależność:

$$
g^{*}=3-\frac{5}{2 a^{*}}
$$

oraz

$$
g^{+}=7-\frac{5}{2 a^{+}} \text {dla } 2 \mathrm{a}^{*}<4 \mathrm{~m}
$$

natomiast dla układów biegowych przy $2 \mathrm{a}^{*}>4 \mathrm{~m}$ obowiązuje zależność:

$$
g^{+}=\frac{15}{2 a^{+}}+2
$$

Analizując dalej kryterium (4) i zakładając, że jednym z czynników powodujących wykolejenie jest odciążenie koła $\Delta \mathrm{Q}$ można wprowadzić pojęcie względnego odciążenia koła $\Delta \mathrm{q}$, które można wyrazić za pomocą następującego wzoru:

$$
\Delta q=\frac{\Delta Q}{Q_{o j}}
$$

Wówczas graniczne odciążenie koła $\lim \Delta \mathrm{Q}$ można wyrazić wzorem:

$$
\lim \Delta Q=Q_{o j} \cdot \lim \Delta q
$$

Wstawiając (44) do zależności (4) otrzymuje się:

$$
\frac{Y}{Q_{o j}-\lim \Delta Q}=\lim \left(\frac{Y}{Q}\right)_{a}
$$

lub inaczej:

$$
\frac{Y}{Q_{o j}-Q_{o j} \cdot \lim \Delta q}=\lim \left(\frac{Y}{Q}\right)_{a}
$$

Po przekształceniach otrzymuje się następującą zależność:

$$
\lim \Delta q=\frac{\lim \left(\frac{Y}{Q}\right)_{a}-\frac{Y_{a}}{Q_{o j}}}{\lim \left(\frac{Y}{Q}\right)_{a}}
$$

Zastępując $\lim \left(\frac{Y}{Q}\right)_{a}$ wartością 1,2 otrzymuję się następującą zależność: 
lub inaczej:

$$
\lim \Delta q=\frac{1,2-\frac{Y_{a}}{Q_{o j}}}{1,2}
$$

$$
\lim \Delta Q=\frac{1,2 \cdot Q_{o j}-Y_{a}}{1,2}
$$

Taka postać równania pozwala na ustalenie dopuszczalnego względnego odciążenia koła $\lim \Delta \mathrm{q}$ jako funkcji średniego nacisku koła oraz wielkości siły prowadzącej $Y_{\mathrm{a}}$ ( po zewnętrznej stronie łuku toru), która jest określona jako $\mathrm{Y}_{\mathrm{a}}=\mathrm{f}\left(\mathrm{a}_{\mathrm{q}}, \mathrm{Q}_{\mathrm{oj}}\right)$. W raporcie ORE B55 Rp.8 [15] podano przybliżone wzory na obliczenie tej siły $\mathrm{Y}_{\mathrm{a}}$ ( jak również $\mathrm{Y}_{\mathrm{i}}$-tzn, siły prowadzącej dla koła znajdującego się po stronie wewnętrznej łuku) dla wagonów towarowych wyposażonych w wózki standardowe Y25 o bazie $1,8 \mathrm{~m}$ oraz $\mathrm{w}$ wózki 661 (z możliwością quasiradialnego ustawiania się zestawów kołowych) posiadające zestawy kołowe z kołami o profilu tocznym S1002 wg karty UIC 510-2 [10] dla zakresu przyspieszeń poprzecznych $-0,5 \mathrm{~ms}^{-2}$ $\leq \mathrm{a}_{\mathrm{q}} \leq 0,85 \mathrm{~ms}^{-2}$. Równania na obliczenie sił prowadzących $\mathrm{Y}_{\mathrm{a}}$ lub $\mathrm{Y}_{\mathrm{i}}$ zostały ustalone na podstawie badań doświadczalnych przeprowadzonych $\mathrm{z}$ wagonami towarowymi wyposażonymi $\mathrm{w}$ zestawy kołowe pomiarowe na jednym $\mathrm{z}$ wózków na trasach $\mathrm{DB}$, posiadających łuki z zakresem promieni $225 \mathrm{~m}<\mathrm{R}<1000 \mathrm{~m}$. Po wyliczeniu siły prowadzącej $Y_{a}$ oraz przy znanym średnim ( nominalnym) nacisku koła na szynę $Q_{\mathrm{oj}}$ można wyznaczyć wartość $\lim \Delta \mathrm{q}$.

Pomiary sił prowadzących dla pojazdów towarowych dwuosiowych $\mathrm{z}$ klasycznym zawieszeniem dwuwieszakowym przeprowadzone na tuku o promieniu $\mathrm{R}=150 \mathrm{~m}$ wykazały, że siła prowadząca koła znajdującego się po stronie zewnętrznej łuku toru $Y_{a}$ jest równa sile oporu tarcia ślizgowego $Y_{i}$ koła znajdującego się po wewnętrznej stronie łuku toru.

$\mathrm{Z}$ tego wynika przybliżona zależność:

$$
Y_{a} \approx Y_{i}=Q_{i} \cdot \operatorname{tg}(\gamma+\rho)
$$

przy równoczesnym obowiązywaniu wzoru:

$$
\operatorname{tg}(\gamma+\rho) \cong \frac{6,5}{150} \cdot 2 a^{*}
$$

Z powyższych zależności można wyprowadzić wzór na dopuszczalne odciążenie względne wagonów towarowych dwuosiowych zgodnie $\mathrm{z}$ raportem ORE B55 Rp.8 [15]:

$$
\lim \Delta q=\frac{1,2-\operatorname{tg}(\gamma+\rho)}{1,2+\operatorname{tg}(\gamma+\rho)}
$$

Wartości dopuszczalnego względnego odciążenia zestawu koła $\lim \Delta$ q dla wagonów towarowych dwuosiowych wyposażonych w klasyczne zawieszenie dwuwieszakowe $\mathrm{z}$ resorami piórowymi ( o charakterystyce liniowej lub progresywnej ) przedstawiono $\mathrm{w}$ tabeli 4.
Zestawienie wartości lim $\Delta q$ dla wagonów towarowych dwuosiowych wyposażonych w zawieszenie klasyczne z resorami piórowymi

Tabela 4

\begin{tabular}{|c|c|c|c|c|}
\hline L.p. & $\begin{array}{c}\text { Baza } \\
\text { pojazdu } \\
{[\mathrm{m}]}\end{array}$ & $\operatorname{tg}(\gamma+\rho)$ & $\lim \Delta \mathrm{q}$ & Uwagi \\
\hline 1 & 4,5 & 0,1949 & 0,720 & \\
\hline 2 & 5 & 0,2166 & 0,694 & \\
\hline 3 & 6 & 0,2599 & 0,643 & \\
\hline 4 & 7 & 0,3033 & 0,596 & \\
\hline 5 & 8 & 0,3466 & 0,551 & \\
\hline 6 & 9 & 0,3899 & 0,509 & \\
\hline 7 & 10 & 0,4333 & 0,469 & $*$ \\
\hline
\end{tabular}

* graniczna baza wagonów towarowych dwuosiowych ( dla wyprodukowanych wagonów z rozsuwanymi ścianami)

Badania doświadczalne wykolejeń wagonów towarowych dwuosiowych przeprowadzone w latach sześćdziesiątych ubiegłego wieku i mające na celu określenie $\lim \Delta \mathrm{q}$ wykazały [8], że $\lim \Delta \mathrm{q}$ zawiera się w przedziale $0,62 \leq \lim \Delta q \leq 0,84$ (przy otrzymanej średniej ze stu pomiarów $\left.\lim \Delta \mathrm{q}_{\text {sir }}=0,73\right)$. Wyniki tych badań pokrywają się z otrzymanymi na drodze analitycznej ze wzoru (48) zwłaszcza, że w omawianym okresie budowano wagony o małych bazach. Jak podaje [8], przeważały wtedy wagony towarowe o bazie $2 \mathrm{a}^{*}=5 \mathrm{~m}$. Zgodnie z zaleceniami raportu ORE B55 Rp.8 [15] współczynnik wykolejenia dla wagonów towarowych dwuosiowych, można wyznaczyć w oparciu o parametry wyznaczone na drodze badań:

$$
\left(\frac{Y}{Q}\right)_{a}=\frac{\left(Q_{o j}+Q_{f z O}+\Delta Q_{t} \pm \Delta Q_{F y}\right) \cdot \operatorname{tg}(\gamma+\rho)+F_{y}}{Q_{o j}-\Delta Q_{f z o}-\Delta Q_{t} \pm \Delta Q_{F y}}
$$

Oznaczenia sił pionowych przyjęto na podstawie wzoru (33), natomiast siła Fy jest poprzeczną siłą łożyskową (rys.3).

\section{Wnioski}

Jak wynika z przeprowadzonych analiz, kryteria bezpieczeństwa przed wykolejeniem sa przedmiotem dalszych prac analitycznych oraz doświadczalnych. Z jednej strony jest to wymuszone rozwojem nowych pojazdów o niekonwencjonalnej budowie, jakimi są pojazdy bimodalne ( RoadRailer, Transtrailer, Kombitrailer) oraz wagony do przewozu samochodów ciążowych typu "Rollende Landstrasse" ( posiadające bardzo małe średnice kół), z drugiej zaś strony rozwojem nowoczesnych tras kolejowych ( $\mathrm{np}$. dostosowanych do wysokich prędkości). Przy formułowaniu kryteriów dotyczących tego zagadnienia okazało się, że zbyt ostre wymagania powodują znaczne zwiększenie kosztów wytwarzania pojazdów oraz duże koszty utrzymania infrastruktury kolejowej (np. duże nakłady finansowe na prace remontowe) co powoduje 
niską konkurencyjność transportu szynowego w stosunku do innych rodzajów transportu. Argument ten należy tym bardziej uznać za istotny, że w roku 2002 udział transportu szynowego w przewozie ładunków wynosił zaledwie 12,9 \% w stosunku do 75,5\% dla transportu drogowego, biorąc pod uwage łącznie 15 krajów członkowskich Unii Europejskiej (udział transportu za pomocą żeglugi śródlądowej oszacowano na $6 \%$, natomiast rurociagowej na 5,6\%). Absolutny "rekord" w tej niekorzystnej statystyce dla transportu towarów biją takie kraje jak Grecja $(1,9 \%$, $98,1 \%)$, Irlandia ( $3.9 \%, 96,1 \%)$, Holandia ( $4,4 \%$, $44,9 \%)$, Hiszpania ( 89,3\%, 6,4 \%). Statystykę w analizowanym czasookresie niewiele poprawiło wliczenie przyjętych w 2004 roku 10-ciu krajów członkowskich, gdzie proporcje te wynosiły odpowiednio $16,3 \%$ dla transportu szynowego oraz 72,2 \% dla transportu drogowego. Prace nad formułowaniem nowych kryteriów nie mogą na pewno odbywać się kosztem bezpieczeństwa kursującego taboru. Jednak używanie w tym przypadku rachunku prawdopodobieństwa, zgodnie $\mathrm{z}$ wytycznymi raportu ORE B55 Rp.8 [15], wydaje się być całkowicie uzasadnione. W wyniku takiego ujęcia zagadnienia okazuje się, że utrzymanie współczynnika wykolejenia (Y/Q) na poziomie 1,2 daje 95\% prawdopodobieństwa, że pojazd nie wykolei się, albo inaczej producent i użytkownik pojazdu ponoszą 5\% ryzyka, że wykolejenie wystąpi w przypadku jednoczesnego pojawienia się wszystkich ekstremalnych, niekorzystnych zjawisk ( pojazd o dużej sztywności skrętnej, graniczna wichrowatość toru oraz zły stan jego utrzymania). Podobnie łagodzenie kryteriów dotyczących ograniczenia wielkości sił poprzecznych $\Sigma Y$ mogących wywołać przesunięcia boczne toru musi być prowadzone przy bardzo dużym udziale prac badawczych. Należy wziąć pod uwagę, że już przy istniejących kryteriach służby budowlane muszą uwzględnić w obliczeniach skrajni trwałe przesunięcie poprzeczne toru wynoszące $15 \mathrm{~mm}$, które jest dopuszczalne pomiędzy dwoma okresami naprawczymi. Z przedstawionych analiz kryteriów wynika, że konieczna jest ścisła współpraca pomiędzy konstruktorami pojazdów, użytkownikami oraz służbami budowlanymi, aby realnie zapewnić maksymalne bezpieczeństwo kursującego pojazdu.

\section{Literatura}

[1] Bałuch H.: Optymalizacja układów geometrycznych toru. WK i t. Warszawa.1983

[2] Böhmer A., Ertz M., Konothe K., Bucher-Mersch $F$., Klimpel T. : Beanspruchungen von Schienen unter dynamischen und thermischen Belastungen. ZEVRail Glasers Annalen. Nr 03/04.2003

[3] Jakob J., Schubert S.: Innovative Fahrwerke TR400- Entwicklung und Erprobung der künftigen Hochgeschwindigkeitswerke. ZEVRail Glasers Annalen. 8.2004.
[4] Kik W., Menssen R., Moelle D.: Kräfte und Verschleiß in der Wendenschleife und im Abzweig einer Weiche. EI- Der Eisenbahningenieur 04.2003.

[5] Kish A.: Neue Gleisverschiebungskräfte für Hochgeschwindigkeitsstrecken. Schienen der Welt. $7 / 8.2001$.

[6] Krugmann H.L.: Lauf der Schienenfahrzeuge im Gleis. Eine Einführung. Oldenbourg Verlag München-Wien.1982.

[7] Riessbeger K.: Zur Entgleisungssicherheit der Rollenden Landstrasse. ZEVRail Glasers Annalen. $\mathrm{Nr} 2 / 3.1994$

[8] Smolarz W., Sobolewski H., Basiewicz T., Batuch T., Statkiewicz J.: Przystosowanie kolei do zwiększonych szybkości $i$ dużych przewozów. Praca zbiorowa. WK i Ł. Warszawa 1969

[9] Sysak J.: Drogi kolejowe. PWN. Warszawa 1982.

[10] Karta UIC 510-2: Pojazdy doczepne. Kota i zestawy kolowe. Warunki do stosowania kót o różnych średnicach. Wydanie 4 z 04.2004

[11] Karta UIC 518: Badania i homologacja pojazdów kolejowych z punktu widzenia właściwości dynamicznych, bezpieczeństwa jazdy, obciażenia toru i parametrów biegowych. 2-gie wydanie $z$ 01. 2003.

[12] Karta UIC 518-2: Uzupetnienie do karty UIC 518: Zastosowanie do wagonów towarowych przystosowanych do nacisku zestawu kołowego większego niż 22,5 t i do 25t. 1-sze wydanie z 06. 2004.

[13] pr EN 14 363:2002 Bahnanwendungen- Prüfung für die fahrtechnische Zulassung von Schienenfahrzeugen -Prüfung des Fahrverhaltens und stationäre Versuche. Juni 2002.

[14] Przepisy D1- Przepisy techniczne utrzymania i eksploatacji nawierzchni kolejowej na liniach kolejowych normalnotorowych uzytku publicznego, wprowadzone zarzqdzeniem $\mathrm{nr} 47$ Ministra Komunikacji z dn.01.01.1982, wchodzace $w$ życie $z$ dniem 01.05.1983.

[15] Raport ORE Frage B55 : Sicherheit gegen Entgleisen von Güterwagen in Gleisverwindungen. Bericht Nr.8 (Schlussbericht). Utrecht, April 1983.

[16] Raport ORE Frage C138: Zulässige Höchstwerte der Y-und Q-Kräfte und Entgleisungskriterien. Utrecht 1986. 